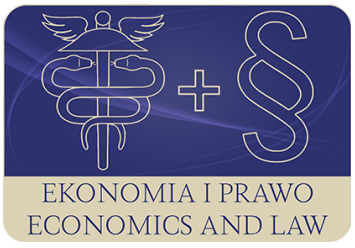

EKONOMIA I PRAWO. ECONOMICS AND LAW

Volume 20, Issue 2, June 2021

p-ISSN 1898-2255, e-ISSN 2392-1625

www.economicsandlaw.pl

ORIGINAL ARTICLE

received 30.03.2021; revised 20.06.2021; accepted 30.06.2021

Citation: Podstawka, M., \& Podstawka, Ł. (2021). Concept for legal and economic changes to the pension insurance of farmers. Ekonomia i Prawo. Economics and Law, 20(2), 367-381. https://doi.org/10.12775/EiP.2021.022.

\title{
Concept for legal and economic changes to the pension insurance of farmers
}

\author{
MARIAN PODSTAWKA \\ corresponding author \\ Institute of Agricultural and Food Economics, National Research Institute, Department of Finance \\ and Risk Management, ul. Świętokrzyska 20, 00-002 Warszawa, Poland \\ $\square$ marian.podstawka@ierigz.waw.pl \\ (D) orcid.org/0000-0002-3834-0743 \\ ŁUKASZ PODSTAWKA \\ Warsaw Univeristy of Life Sciences, Faculty of Economics, Institute of Economics and Finance, \\ Poland \\ ๑lukasz_podstawka@sggw.pl \\ (D) orcid.org/0000-0002-7394-0218
}

\begin{abstract}
Motivation: The study presents the current conditions for receiving the agricultural pension from the Agricultural Social Insurance Fund (KRUS) and the rules for calculating it. They are organised in such a way that the longer the insurance period of the insured person, the lower the so-called supplementary part of their pension than in the case of the insured person with the shorter insurance period. In addition, since 2011, persons insured in KRUS and having farms with an area of more than 50 ha of utilised agricultural area have been obliged to pay higher amounts for their pension insurance which do not have any impact on the level of benefits received. Farmers who also run business activities are treated by the insurance legislation in a similar manner. Hence, there is a need to make changes to the legal and economic regulations in KRUS, which would reflect the new conditions of management in Poland after 1989 and the solutions existing in the Social

Insurance Institution (ZUS).

Aim: The objective of the study is to identify the regulations related to agricultural pension insurance which are inadequate in relation to the existing conditions of management in our country and to the solutions existing in ZUS. In addition, the objective of the paper is to propose changes to the insurance regulations of KRUS concerning the rules for
\end{abstract}


calculating pensions and the definition of special branches of agricultural production. Also, the effects of these changes from the viewpoint of the insured person have been presented.

Results: The result of the study is a proposal for changes to the rules for calculating pensions for farmers insured in KRUS. The paper proposes to split the pension from KRUS into three parts: the contribution part, supplementary part and capital part. The proposals presented differentiate the pension amount depending on the insurance period and additionally paid contributions. The paper proposes to extend the special branches of agricultural production and to adopt income they generate at the level of $50 \%$ of the average salary in the national economy or at the level of the minimum wage as a criterion for access to insurance in KRUS.

Keywords: agricultural insurance; social insurance; agricultural pension; KRUS JEL: H55; J26; G52; Q14

\section{Introduction}

The basic form of the current legal solutions regarding social insurance for farmers was introduced by the Act on social insurance of farmers (1990). Some quite substantial changes to these regulations were introduced by the Act on certain financial securities (2004). Both the basic act and its amendment contain the legal regulations which have become outdated. They do not correspond to the market economy rules or to the existing social insurance rules implemented by ZUS, which were modified in 1999.

The objective of the study is to identify the regulations related to agricultural pension insurance which are inadequate in relation to the existing conditions of management in our country and to the solutions existing in ZUS. In addition, the objective of the paper is to propose changes to the insurance regulations of KRUS concerning the rules for calculating pensions and the definition of special branches of agricultural production. Also, the effects of these changes from the viewpoint of the insured person have been presented.

The study presents the current conditions for receiving the agricultural pension from the Agricultural Social Insurance Fund (KRUS) and the rules for calculating it. They are organised in such a way that the longer the insurance period of the insured person, the lower the so-called supplementary part of their pension than in the case of the insured person with the shorter insurance period. In addition, since 2011, persons insured in KRUS and having farms with an area of more than 50 ha of utilised agricultural area have been obliged to pay higher amounts for their pension insurance which do not have any impact on the level of benefits received. Farmers who also run business activities are treated by the insurance legislation in a similar manner. Hence, there is a need to make changes to the legal and economic regulations in KRUS, which would reflect the new conditions of management in Poland after 1989 and the solutions existing in the Social Insurance Institution (ZUS).

The special branches of agricultural production require regulatory changes. There are 10 types of them which are valid for the purposes of KRUS. In addi- 
tion, currently the production norms classifying the given type of production as a special branch are not logically normative. For example, the cultivation of ornamental plants and plants in heated greenhouses of more than $100 \mathrm{~m}^{2}$ is considered a special branch for the purposes of KRUS. In addition to this activity, keeping apiaries of more than 80 families is considered a special branch. While the latter can bring monthly income at the level of the minimum wage in the national economy, $100 \mathrm{~m}^{2}$ of a greenhouse will not bring such income.

The study proposes changes to the rules for calculating pensions for farmers insured in KRUS. Four research hypotheses have been verified, i.e.:

1. The rules for calculating pensions for persons insured in KRUS do not correspond to the market economy rules.

2. The rules for calculating pensions in KRUS represent the principles of the socialist economy.

3. The higher contributions paid by persons insured in KRUS are not reflected in the amount of the pensions they receive.

4. The new regulation is required for the special branches of agricultural production for the purposes of KRUS as they are not logically normative.

The study proposes to divide the pension from KRUS into three parts, i.e. the contribution part, supplementary part and capital part. The presented proposals differentiate the pension amount depending on the insurance period and additionally paid contributions. The paper proposes to extend the special branches of agricultural production and to adopt the income they generate at the level of $50 \%$ of the average salary in the national economy or at the level of the minimum salary as a criterion for access to insurance in KRUS.

The study makes use of the literature, legal acts and experience from meetings with farmers during various types of training courses. To verify the hypotheses and achieve the objectives of the study, the following methods have been used: descriptive, financial analysis and inference.

\section{Review of the literature and expert opinions}

The present study describes the functioning of the social insurance system for farmers. It addresses the assessment of pension insurance and the proposals to change it, including an indication of the implications for insured persons. It should be stressed that the subject of the functioning of pension insurance for farmers is rarely described in scientific studies. The limited literature in this field raises the problem that the current conditions and rules regarding the level of basic benefits have developed in an evolutionary manner (Piątkowski, 1979). At present, as regards contributions, for insured persons having the farm of up to 50 ha of utilised agricultural area and not running additional agricultural activities, the pension insurance contribution is determined at the same amount for each insured person. Contributions paid in the same amount by small farmers and farmers with farms with an area of a dozen or so ha do not respect the principle of the insurance capacity of insured persons. In addition, pen- 
sion and disability pension benefits are equally subsidised by the state for both wealthy and poorer farmers. As a result, the former make use of the so-called national solidarity (Jagła, 2014). The literature and expert opinions stress that the pension and disability pension system of social insurance for farmers benefits from a large amount of co-financing and does not include tools to stimulate desirable changes in the agrarian structure (Chmieliński et al., 2009; Jagła, 2014; Kowalski \& Kulawik, 2005; Tryfan, 2000). It is worth mentioning the work of the team representing the European Fund for the Development of Polish Villages, presenting the Concept for the reform of the insurance system for farmers (Neneman et al., 2012). The authors suggest identifying three groups of farms: those with low income whose users will be insured according to the existing rules; those with medium income, whose users will pay proportionally higher contributions and receive higher benefits; and those with high income, whose users will be insured under the general system. Therefore, this and other proposals raise the problem of calculating income (revenues) of farms as a basis for determining differentiated contributions (PAP, 2014). The current rules regarding the level of basic benefits for farmers do not take into account their insurance contributions. Even worse - the longer the insurance period of the insured person, the higher the pension benefit they receive (Podstawka, 1998). Insured persons paying higher pension contributions (i.e. farmers also running non-agricultural activities and having more than 50 ha of utilised agricultural area) do not receive higher benefits (Act on certain financial securities, 2004).

As regards the special branches of agricultural production, they are characterised by dualism in terms of types and norms, for the purposes of social insurance and for the purposes of personal income tax (PIT) (Podstawka \& Podstawka, 2018). Currently, for the purposes of KRUS, 10 types of special activities are taken into account, together with increased production norms when compared to those applicable to PIT. In addition, these 10 types of special branches of agricultural production for the purposes of KRUS are not logically normative. They include the branches which give persons involved in them an opportunity to make a living and those which are unable to provide this amount of income. The problem of changes in the area of pension and disability pension insurance for farmers has been raised in the literature for many years (Walczak, 2017). The problem of increased contributions paid by some farmers and the lack of pension effects in this regard is raised. In general, the insured themselves rate the pension insurance system positively but point to a need to modify it (Kisiel et al., 2013).

\section{Research methods}

The descriptive analysis and logical inference methods have been used in the study to assess the currently existing rules for calculating pensions from KRUS. With regard to assessing the effects of suggested changes to the pension amount for farmers, the financial analysis and simulation methods have been used. The sim- 
ulation and tabular methods have been used to calculate the individual contribution rate in the years 1983-1990.

Using these methods, the amount of the hypothetical pensions from KRUS has been determined for two insured persons, one with an insurance period twice as long as the other.

\section{Current conditions for receiving the agricultural pension}

Issues regarding the amount of the agricultural pension are governed by the Act on social insurance of farmers (1990). Back then, just like several years before, the Polish economy was in crisis. The country had problems with supplying food products to cities. In this situation, it was decided to use the legislation on social insurance for farmers so as to improve the supply to cities and, previously, to increase the agricultural production. Thus, such solutions were introduced in order to accelerate the rotation of generations in agriculture and the growth in its production, assuming that the successor, a young farmer, would be more innovative and more efficient. This was seen as an opportunity to improve the productivity of Polish agriculture and the supply of food products to cities. Over time, these hopes have proved futile. Firstly, as regards the conditions for receiving the pension and the rules for calculating it, they are not known to the insured farmers ${ }^{1}$. Secondly, even if they were known to them, the transfer of the farm to a successor or the sale of this farm is determined by completely different reasons than the criteria for receiving the pension and the rules for calculating it.

Pursuant to the provisions of the Act on social insurance of farmers (1990), the main benefit for farmers, i.e. the pension, consists of two parts:

- contribution part,

- supplementary part.

Pensions were divided into those two parts so as to compensate for the unfair practices that took place before 1990. If the insured farmer met the age and insurance period requirements to receive the pension, but did not cease agricultural activities, they did not receive the pension benefit. In addition, they were obliged to pay contributions. Such restrictions were not applied to those insured with ZUS. Entrepreneurs practising liberal professions and many persons from other professional groups received pensions after meeting the age and insurance period requirements without the need to cease their previous activity. Therefore, in 1990 it was decided that the insured farmer, if they met the age and insurance period requirements and continued to manage the farm, would receive part of the pension, i.e. the contribution part.

${ }^{1}$ Co-author M. Podstawka carried out around 200 training courses for around 5,000 farmers in the years 2014-2015 as well as in 2020 and did not meet any farmer who would be familiar with the rules for calculating pensions. 
As regards the conditions for receiving the contribution part of the pension from KRUS, they are as follows: the insured person should meet both of the two criteria, i.e. in the case of women:

- 60 years of age or more and a 25-year insurance period and in the case of men

- 65 years of age and a 25-year insurance period.

The legislation also provides for the possibility of granting the contribution part of the agricultural pension to the insured farmer if they meet both of the following requirements by 31 December 2017:

- reaching the age of 55 - in the case of a woman, or 60 - in the case of a man;

- being covered by pension and disability pension insurance for at least 30 years.

The following periods are included in the insurance period of the person insured in KRUS:

- managing of or working on a farm after reaching the age of 16 before 1 January 1983;

- being covered by social insurance for individual farmers and their family members in the years 1983-1990;

- being covered by social insurance for farmers from 1 January 1991 until retirement.

When determining the right to the agricultural pension for persons born after 31 December 1948, the period of non-agricultural insurance shall not be taken into account. However, if such a person, after reaching the retirement age and having a 25 -year insurance period, becomes entitled to receive the agricultural pension and occupational pension, they shall receive both benefits.

If the insured person is to receive the full pension consisting of the contribution part and the supplementary part, they are obliged, in addition to meeting the age and insurance period criterion, to cease agricultural activity. This requirement will be met if the insured person leaves for themselves less than 1 equivalent ha of their farm or does not have and pursue a special branch of agricultural production. On the other hand, the remaining parts of the farm may be:

- sold,

- leased,

- handed over to a successor.

\section{Rules for calculating the agricultural pension}

As regards the contribution part of agricultural pension, the general rule is that $1 \%$ of the basic pension is available for each year of the insurance period. However, this general rule does not apply to period II. Period II requires the establishment of the so-called individual contribution rate. The reason for this is that back then the Act on social insurance of individual farmers and members of their families (1982) was in force. This Act, like no other act before, determined insurance contributions for farmers and their family members depending on the number of hectares of utilised agricultural area and the number of persons 
covered by insurance. The calculation of contributions in this way led to a significant burden on insured persons with large farms. In order to meet these rules, the above-mentioned individual contribution rate shall be determined for each year in the period 1983-1990. For the purpose of determining it, the sum of contributions paid for persons and hectares of utilised agricultural area shall be taken into account, then these amounts shall be divided by the number of insured persons and the resulting quotient shall be applied to $120 \%$ of the basic pension in each year of that period. The calculation of this rate will be illustrated by an example in which it was assumed that we had one insured person who paid contributions in relation to a farm with an area of 10 ha. Table 1 shows the method and value of calculating the individual contribution rates in the years 1983-1990.

Therefore, for the hypothetical insured person, an individual contribution rate of 17 is determined.

As regards period I, it is divided into two sub-periods. The first begins when the insured person reaches the age of 16 by 30 June 1977. This is the time when the Act on retirement benefits and other benefits for farmers and their families (1997) was in force. For each year of this period, $0.5 \%$ of the basic pension shall be determined. This rate is reduced as there was no obligation to pay contributions at that time. The second time interval from period I shall begin on 1 July 1977 and end on 31 December 1982. During that period, the contribution part shall be determined as $1 \%$ of the basic pension for each year of insurance coverage. Assuming that our hypothetical insured person is a woman born on 1 January 1961, who in January will hand over the farm to a successor and in February 2021 will apply for the agricultural pension, showing the following insurance periods:

- from 1 January 1976 to 30 June 1977, work on the parents' farm (this period is included in the insurance period);

- from 1 July 1977 to 31 December 1982, work on own farm (5\%);

- from 1 January 1982 to 31 December 1990 work on own farm (17\%) according to Table 1;

- from 1 January 1991 to 31 December 2021, work on own farm (30\%).

Therefore, our insured person has collected 52\% in total, which is applied to the basic pension amounting to PLN 972.40 as from 1 March 2020, making the contribution part of the pension equal to PLN 505.65 (PLN 52\% x PLN 972.40).

In this case, the insured person will receive PLN 826.50 in the supplementary part. This is equivalent to $85 \%$ of the basic pension, as this part of the benefit cannot be lower than this value. For our insured person, this would be a lower value, in accordance with the rule that for each year above 20 years adopted for determining the contribution part, excluding period II, the supplementary part is reduced by $0.5 \%$. Therefore, this reduction would be: $(52-17)-20 \times 0.5=7.5 \%$ and $95 \%$ of the supplementary pension should be reduced by this amount. As a result, this part of the pension would amount to $82.5 \%$ of the basic pension. 
Taking into account the amount of the contribution part (PLN 505.65) and (PLN 826.50) of the supplementary part, our insured person will receive a total of PLN 1,332.15 of the agricultural pension. With the amount of this benefit calculated, KRUS determines its ratio to the basic pension. In our case, it will be (PLN 1,332.15/PLN 972.40)=1.37. This ratio remains unchanged throughout the period of receiving the pension. Its new value shall be determined each year, from 1 March, along with the change to the basic pension, taking into account the predetermined ratio ${ }^{2}$.

The rules presented regarding the amount of agricultural pension take into account the principles of socialist egalitarianism. They are organised in such a way that the amount of the supplementary part of the agricultural pension is inversely correlated with the insurance period. As a rule, the longer the insurance period, the lower this part of the pension. In turn, the contribution part is positively correlated with the insurance period. As a result, insured persons with long and short insurance periods receive similar pensions. We will illustrate this with the following examples.

Example 1. An insured person with a 20-year insurance period will receive:

- contribution part of the pension (20\% x PLN 972.40)=PLN 195.50;

- supplementary part of the pension (95\% x PLN 972.40)=PLN 923.8;

- in total, the pension will amount to PLN 1,119.30.

- Example 2. An insured person with a 40-year insurance period will receive:

- contribution part of the pension (40\% x PLN 972.40)=PLN 388.96;

- supplementary part of the pension 95\%-(40-173-20) x $0.5 \%$ x PLN 972.40=PLN 909.19;

- in total, the pension will amount to PLN 1,298.15.

Thus, the difference in the pension amount between the insured persons presented in our examples is PLN 179. However, the insured person from Example 1 had an insurance period which was twice shorter than the insurance period of the insured person from Example 2, who had twice higher insurance contributions. It should be stressed that if the difference in the insurance period was higher between the insured persons, then the difference in the pension amount would be even smaller. Thus, the first two research hypotheses are confirmed.

\section{Special branches of agricultural production for the purposes of KRUS}

The special branches of agricultural production are a basis for covering persons involved in them with insurance in KRUS. By 2 April 2004, they were defined in the same way, both for the purposes of PIT and for the purposes of social in-

${ }^{2}$ From 1 March 2021, the amount of the basic pension shall be PLN 1,013.63.

${ }^{3} 17$ years - the individual contribution amount at the time when the Act on social insurance of individual farmers and members of their families (1982) was in force (adopted from Table 1) which is not taken into account for the amount of the supplementary part of the agricultural pension. 
surance. The aforementioned Act on certain financial securities (2004) introduced regulatory changes concerning the special branches of agricultural production. Currently, these branches, for the purposes of KRUS insurance, are represented by 10 types of these branches. For the purposes of PIT, there are still 17 of them and they have different production norms. Table 2 lists the special branches for the purposes of KRUS insurance, together with their normative sizes.

In addition to a reduction in the number of special branches to 10 in 2004 for the purposes of KRUS, their norms were increased in relation to those which are still applicable for the purposes of PIT. For example, in the case of cultivation in greenhouses, plastic tunnels and cultivation of mushrooms and mycelium, the norms for these activities are 4 times higher for social insurance purposes than for the purposes of personal income tax. It is worth stressing that there is a normative imbalance among the special branches for the purposes of KRUS. This applies to the branches such as 80 bee families, 2,000 laying hens and 100 pigs. According to the data in Table 3, these branches may constitute a source of maintenance for persons involved in them. On the other hand, the cultivation in the area of $100 \mathrm{~m}^{2}$ in a heated greenhouse, in $200 \mathrm{~m}^{2}$ of a heated plastic tunnel or $100 \mathrm{~m}^{2}$ of mushrooms is unable to provide sufficient income for persons involved.

Table 3 presents the income results of farms keeping agricultural accounting for the purposes of the Polish FADN ${ }^{4}$ and specialised in the selected special branches of agricultural production.

\section{Results: proposals for changes to the rules for calculating agricultural pensions and disability pensions and to the regulations defining the special branches of agricultural production for the purposes of KRUS}

The proposed changes to the pension amount result from the market rules introduced in our economy in 1989 and from the regulations introduced to ZUS by the reform of 1999 . Therefore, it is time to apply them to social insurance for farmers as part of KRUS.

The proposal for changes regarding the pension amount for farmers is as follows:

1. It is necessary to maintain the division of pension (disability pension) into the contribution part and the supplementary part.

2. For all insured persons meeting the basic pension requirements (woman 60 years of age, man -65 years of age and a 25 -year insurance period), it should be:

${ }^{4}$ FADN - Farm Accountancy Data Network is the European farm accountancy data collection system implemented by the Institute of Agricultural and Food Economics National Research Institute. 
- in the contribution part - equivalent to $25 \%$ of the basic pension;

- in the supplementary part - $75 \%$ of the basic pension.

Summing up, the insured person would receive the pension equal to the basic pension (PLN 972.40). We suggest dividing it into two parts, should the insured person not cease agricultural activities. Then, as it is so far, they would receive only $25 \%$ of the basic pension as the contribution part of the pension.

3. In addition, for insured persons with the insurance period of more than 20 years:

- the additional contribution part should be determined as a difference between the actual insurance period and 25 years, multiplied by $2 \%$, and this product should be referred to the basic pension, i.e.:

cz. skt. $E=(R s u-25) \times 2 \% \times E p$,

where:

cz. skt. E- contribution part of the pension;

Rsu - actual number of years of the insurance period;

Ep - basic pension;

- the supplementary part would amount to $75 \%$ of the basic pension.

With this proposal, the insured person with the twice longer insurance period, e.g. 50 years, would receive:

- the additional contribution part (50-25) x 2\% x PLN 972.40=PLN 486.20;

- and the contribution part due for the first 25 years amounting to PLN 243.10 (25\% x PLN 972.40).

In total, the contribution part of the pension would be PLN 486.20 + PLN 243.10=PLN 729.30.

If our insured person ceased agricultural activity, in addition to this part of the pension they would be entitled to receive the supplementary part of the pension which would amount to $75 \%$ of the basic pension. The supplementary part is therefore PLN $972.40 \times 75 \%=$ PLN 729.30 .

In this situation, the total pension would amount to PLN 1,458.60 and would be much higher in relation to the insured person whose insurance period is twice shorter. The difference would amount to PLN 486.20 (PLN 1,458.60 PLN 972.40), unlike the current situation, where these differences are nominal (PLN 179).

4. For persons paying additional pension contributions according to Table 3, the capital part of the pension should be calculated, according to the solutions in place in ZUS, i.e.:

$$
E k=\frac{\sum S k z}{\bar{x}}
$$


where:

Ek - capital part of the pension;

$\Sigma S k z$ - the sum of valorised contributions since 2011 for farmers with farms of more than 50 ha and since 2005 for farmers who are involved both in agricultural and business activities;

$\bar{x}$ - average life expectancy at retirement.

It seems that, as regards the special branches of agricultural production, it would be advisable to depart from defining them by means of production norms. In this case, we can apply an income criterion which is simple to assess as these producers pay income tax. It can be assumed that if the farmer has income from such production which accounts for at least $50 \%$ of the average salary in the national economy, they meet the criterion of access to insurance in KRUS. As regards this access due to the types of production, they should be extended by adopting the same activities for the purposes of KRUS as those applicable to PIT, and perhaps it would be reasonable to extend them, e.g. to include bumblebees, fish, pheasants, earthworms, silkworms, etc.

There is some debate concerning another problem, namely, taxation of the residence left with the property tax. This does not seem justified as the farmer-pensioner's tax capacity is lower than the one they had when managing the farm. Therefore, the residence should be taxed with the agricultural tax, as governed by the Act on Agricultural Tax on Land.

\section{Conclusion}

The rules for calculating agricultural pensions, as presented in the study, result from the socialist egalitarianism doctrine applicable until 1989. It was derived from the principle that "all receive equal amounts and thus it is fair". It seems that 30 years after the transformation of the economic system in Poland, it is time to change the rules for calculating agricultural pensions and disability pensions. The study proposes these changes. According to the proposals presented, the agricultural pension should consist of:

- contribution part, basic and additional,

- supplementary part,

- capital part.

For insured persons with an insurance period of 25 years, it is proposed that the contribution part should be the product of the 25 -year insurance period and $1 \%$ of the basic pension. On the other hand, the supplementary part, for insured persons with an insurance period of more than 25 years, should be the product of double the difference between 25 years and the number of years of the actual insurance period and 1\% of the basic pension. The supplementary part amounts to $75 \%$ of the basic pension value for each insured person. In contrast, the capital part is the quotient of contributions paid and valorised since 2005 and since 2011 divided by the life expectancy at retirement. 
With regard to the special branches, we propose that their number be extended and that the income obtained from them be adopted as a criterion for access to insurance in KRUS. It is possible to adopt the income criterion as these farmers are taxed with PIT on income from the branches of agricultural production. The amount of income obtained is debatable. It may be $50 \%$ of the average salary in the national economy or the value of the minimum wage in the national economy per capita.

We are aware that the proposed changes are subject to debate. They ignore the effects on public finance; we intend to calculate these in the future. Our intention is that this paper should give rise to a discussion on the proposed changes to the rules for calculating pensions for farmers and the definition of special branches of agricultural production.

\section{References}

Chmieliński, P., Goraj, L., Karwat-Woźniak, B., Kowalski, A., \& Sikorska, A. (2009). Instrumenty oddziatywania państwa na ksztattowanie struktury obszarowej gospodarstw rolnych $w$ Polsce, rola systemu ubezpieczenia społecznego rolników w ksztaltowaniu tej struktury, stan obecny i rekomendacje na przysztość oraz propozycje nowych rozwiązań dotyczących tego obszaru dla systemu ubezpieczeń rolników: ekspertyza. IERiGŻ-PIB.

FADN. (2021). Retrieved 10.09.2021 from https://agridata.ec.europa.eu/extensions/FarmEconomyFocus/FADNDatabase.html.

Jagła, W. (2014). Problemy ubezpieczenia spotecznego rolników. IERiGŻ-PIB.

Kisiel, R., Jakubowska, K., \& Królik J. (2013). Znaczenie i przyszłość Kasy Rolniczego Ubezpieczenia Społecznego w polskim rolnictwie. Ubezpieczenia w Rolnictwie: Materiaty i Studia, 49, 25-44.

Kowalski, A., \& Kulawik, J. (2005). Cele, instrumenty i uwarunkowania bieżącej i średniookresowej polityki finansowej w polskim rolnictwie. IERiGŻ-PIB.

Neneman, J., Pilch, M., \& Zagórski, M., (2012). Koncepcja reformy systemu ubezpieczeń spotecznych rolników. EFRWP.

PAP. (2014). Eksperci: koniecznie należy wprowadzić podatek dochodowy dla rolników. Retrieved 10.09.2020 from https://www.pb.pl/ eksperci-rolnicy-powinni-placic-podatek-dochodowy-769165.

Piątkowski, M. (1979). Zaopatrzenie emerytalne rolników. Książka i Wiedza.

Podstawka, M. (1998). Rolnicze ubezpieczenie spoteczne i propozycja ich zmian. SGGW.

Podstawka, M. (2005). Podstawy finansów: teoria i praktyka. SGGW.

Podstawka, M., \& Podstawka, Ł. (2018). Ubezpieczenia społeczne rolników w Polsce po II wojnie światowej: wybrane zagadnienia. Ubezpieczenia $w$ Rolnictwie: Materiaty i Studia, 66, 40-54.

Tryfan, B. (2000). Zabezpieczenia spoteczne rolników w Europie. FAPA. 
Ustawa z dnia 14 grudnia 1982 r. o ubezpieczeniu społecznym rolników indywidualnych i członków ich rodzin [Act of 14 December 1982 on social insurance of individual farmers and members of their families] (Dz.U. $1982 \mathrm{nr} 40$ poz. 268) (Poland).

Ustawa z dnia 2 kwietnia 2004 r. o niektórych zabezpieczeniach finansowych [Act of 2 April 2004 on certain financial securities] (Dz.U. $2004 \mathrm{nr} 91$ poz. 871) (Poland).

Ustawa z dnia 20 grudnia 1990 r. o ubezpieczeniu społecznym rolników [Act of 20 December 1990 on social insurance of farmers] (Dz.U. $1991 \mathrm{nr} 7$ poz. 24) (Poland).

Ustawa z dnia 27 października 1977 r. o zaopatrzeniu emerytalnym oraz innych świadczeniach dla rolników i ich rodzin [Act of 27 October 1977 on retirement benefits and other benefits for farmers and their families] (Dz.U. 1977 nr 32 poz. 140) (Poland).

Walczak, D. (2017). Zmiany w uprzywilejowaniu emerytalnym rolników: reforma bez reformy. Ubezpieczenia w Rolnictwie: Materiaty i Studia, 61, $23-36$.

\section{Acknowledgements}

Author contributions: authors have given an approval to the final version of the article. Authors contributed to this work as follows: M.P. developed the concept and designed the study, M.P. \& E.P. collected the data, M.P. \& E.P. analysed and interpreted the data, M.P. \& E.P. prepared the draft of the article, M.P. \& E.P. revised the article critically for important intellectual content.

Funding: this research was fully funded by the Institute of Agricultural and Food Economics, National Research Institute. 


\section{Appendix}

Table 1.

Example of determining the individual contribution rates for a farm with an area of 10 ha managed by 1 person in the years 1983-1990

\begin{tabular}{|c|c|c|c|c|c|}
\hline \multirow{2}{*}{ Year } & \multicolumn{2}{|c|}{ Amount of contributions (PLN) } & \multirow{2}{*}{$\begin{array}{l}\text { Total contributions } \\
\text { (in PLN/person) }\end{array}$} & \multirow{2}{*}{$\begin{array}{c}120 \% \text { of basic } \\
\text { pension }\end{array}$} & \multirow{2}{*}{$\begin{array}{c}\text { Individual } \\
\text { contribution rate }\end{array}$} \\
\hline & per person & per 1 ha of UAA & & & \\
\hline \multirow[t]{2}{*}{1} & 2 & 3 & 4 & 5 & 6 \\
\hline & & & $(2+3) \times 10 / 1$ & & $(4: 5)$ \\
\hline 1983 & 1200 & 500 & 6200 & 6000 & 1.03 \\
\hline 1984 & 1600 & 800 & 9600 & 6000 & 1.60 \\
\hline 1985 & 1600 & 800 & 96000 & 6000 & 1.60 \\
\hline 1986 & 3400 & 1600 & 19400 & 8000 & 2.43 \\
\hline 1987 & 4650 & 2560 & 30250 & 8400 & 3.60 \\
\hline 1988 & 5810 & 3080 & 36610 & 14440 & 2.50 \\
\hline 1989 & 16080 & 7840 & 94480 & 59500 & 1.60 \\
\hline 1990 & 312000 & 780000 & 1092000 & 414000 & 2.64 \\
\hline
\end{tabular}

Source: Podstawka (2005, p. 254).

Table 2.

List of special branches for the purposes of KRUS insurance

\begin{tabular}{|c|c|c|}
\hline No. & Types of crops and production & Production volumes \\
\hline 1 & $\begin{array}{l}\text { Cultivation of ornamental plants and other plants in heated } \\
\text { greenhouses }\end{array}$ & more than $100 \mathrm{~m}^{2}$ \\
\hline 2 & Cultivation in unheated greenhouses & more than $100 \mathrm{~m}^{2}$ \\
\hline 3 & $\begin{array}{l}\text { Cultivation of ornamental plants and other plants in heated } \\
\text { plastic tunnels }\end{array}$ & more than $200 \mathrm{~m}^{2}$ \\
\hline 4 & Cultivation of mushrooms and mycelium & more than $100 \mathrm{~m}^{2}$ \\
\hline 5 & Poultry for slaughter: & \\
\hline a & chickens & more than 1,000 head (on an annual basis) \\
\hline$b$ & geese & more than 500 head (on an annual basis) \\
\hline c & ducks & more than 500 head (on an annual basis) \\
\hline d & turkeys & more than 500 head (on an annual basis) \\
\hline e & ostriches & more than 20 head (on an annual basis) \\
\hline 6 & Laying poultry & \\
\hline a & laying hens (in the breeding flock) & more than 2,000 head (on an annual basis) \\
\hline $\mathrm{b}$ & geese (in the breeding flock) & more than 200 head (on an annual basis) \\
\hline c & ducks (in the breeding flock) & more than 500 head (on an annual basis) \\
\hline d & turkeys (in the breeding flock) & more than 500 head (on an annual basis) \\
\hline e & hens (production of table eggs) & more than 1,000 head (on an annual basis) \\
\hline $\mathrm{f}$ & ostriches (in the breeding flock) & more than 6 head (on an annual basis) \\
\hline 7 & Poultry hatching establishments (production capacity — nur & er of eggs) \\
\hline a & chickens & more than 3,000 \\
\hline b & geese & more than 3,000 \\
\hline c & ducks & more than 3,000 \\
\hline d & turkeys & more than 3,000 \\
\hline
\end{tabular}




\begin{tabular}{lll}
\hline No. & \multicolumn{1}{c}{ Types of crops and production } & \multicolumn{1}{c}{ Production volumes } \\
\hline $\mathrm{e}$ & ostriches & more than 50 \\
\hline 8 & Fur animals: & more than 50 females of the breeding herd \\
$\mathrm{a}$ & foxes and raccoon dogs & more than 50 females of the breeding herd \\
$\mathrm{b}$ & minks & more than 50 females of the breeding herd \\
$\mathrm{c}$ & polecat-ferret hybrids & more than 50 females of the breeding herd \\
$\mathrm{d}$ & chinchillas & more than 50 females of the breeding herd \\
$\mathrm{e}$ & coypus & more than 50 females of the breeding herd \\
$\mathrm{f}$ & rabbits & more than 80 families \\
\hline 9 & Apiaries & more than 100 head \\
\hline 10 & Breeding and rearing pigs outside the farm & \\
\hline
\end{tabular}

Source: Act on certain financial securities (2004).

Table 3.

Income from selected special branches of agricultural production in the years 2017-2019

\begin{tabular}{|c|c|c|c|c|c|c|}
\hline \multirow{3}{*}{ Types of special production } & \multicolumn{2}{|c|}{2017} & \multicolumn{2}{|c|}{2018} & \multicolumn{2}{|c|}{2019} \\
\hline & \multicolumn{6}{|c|}{ WZT income } \\
\hline & $\begin{array}{l}\text { without } \\
\text { subsidies }\end{array}$ & $\begin{array}{c}\text { with } \\
\text { subsidies }\end{array}$ & $\begin{array}{l}\text { without } \\
\text { subsidies }\end{array}$ & $\begin{array}{c}\text { with } \\
\text { subsidies }\end{array}$ & $\begin{array}{c}\text { without } \\
\text { subsidies }\end{array}$ & $\begin{array}{c}\text { with } \\
\text { subsidies }\end{array}$ \\
\hline $\begin{array}{l}\text { cultivation of ornamental flow- } \\
\text { ers and plants in greenhouses } \\
\text { heated in the area of } 100 \mathrm{~m}^{2}\end{array}$ & $3,008.77$ & $3,153.08$ & $3,238.44$ & $3,349.78$ & $3,352.36$ & $3,477.01$ \\
\hline $\begin{array}{l}\text { cultivation of mushrooms } \\
\text { and mycelium in the area } \\
\text { of } 100 \mathrm{~m}^{2}\end{array}$ & $1,020.26$ & $1,138.92$ & $1,169.39$ & $1,288.79$ & $1,055.23$ & $1,146.30$ \\
\hline $\begin{array}{l}\text { laying hens in the flock } \\
\text { of } 2,000 \text { head }\end{array}$ & $41,976.47$ & $44,819.75$ & $61,786.81$ & $65,821.94$ & $49,200.79$ & $53,780.14$ \\
\hline fatteners - 1,000 head & $48,923.76$ & $67,057.43$ & $26,008.93$ & $47,589.75$ & $75,534.14$ & $96,163.80$ \\
\hline bee families -80 & $14,103.62$ & $16,584.15$ & $24,015.53$ & $25,349.82$ & $21,470.97$ & $25,976.40$ \\
\hline
\end{tabular}

Source: FADN (2021). 
